blood vessels of rabbits following the injection of air into the aorta have shown that the effects of air emboli are not only mechanical but also neurovascular.

\section{Pulmonary Air Embolism}

Forbes (1944) postulated that death in these cases may be due to $(a)$ mechanical interference with the function of the heart through the presence of frothy blood in the right ventricle, to which the signs of cerebral anoxia are secondary; (b) blockage of the pulmonary artery; or (c) the obstructive effects of multiple air emboli in the smaller arterioles of the lungs.

In the case reported above air emboli were not observed in the left side of the heart or in the cerebral arteries, and it was assumed that the air entered the circulation through one of the tributaries of the splenic vein. Air emboli were observed in the portal venous system and parts of the systemic venous circulation. It is therefore of interest to consider whether air emboli are capable of passing through the hepatic sinuses. If air emboli are prevented from passing the hepatic sinuses one of the portal venous systemic anastomoses in the liver may be involved, or one of the collateral portal venous anastomoses. Curtillet and Curtillet (1939c) showed the passage of air emboli from the arterial to the related venous side of the circulation, following the injection of air into the arteries of the limbs of dogs. They concluded that the air passed through the arteriovenous anastomoses in the limbs. These results, however, have not been observed in the internal organs of animals (Curtillet and Curtillet. 1939a. 1939b ; Chase. 1934).

\section{Summary}

A case of arterial air embolism and one of pulmonary air embolism are reported.

The difficulties in the post-mortem diagnosis are discussed.

In each case necropsy was preceded by regional radiographic examinations of the cadavers. The results of these examinations are reported, with radiographs.

It is shown that radiological examinations are a useful adjunct to the actual diagnosis, and also prove a guide to the most advantageous method of dissection to be followed in each case.

Adequate bacteriological examinations are an essential part of the post-mortem investigations.

The mechanism of death in the two types of air embolism is discussed, with special reference to the circulatory pathways involved in the embolic phenomena.

This paper is published by kind permission of Dr. G. W. Gale, Secretary for Health, Union of South Africa. My thanks are due to Dr. B. A. Dormer, chief tuberculosis officer of the Union Health Department, to Dr. I. Gordon, senior government pathologist, Durban, and to Dr. N. Sacks, senior radiologist to the Natal Provincial Administration.

\section{REFERENCES}

Burn, C. G. (1934a). J. infect. Dis., 54, 388

- (1934b). Ibid., 54, 395.

Chase W. H. (1934). Surg. Gynec. Obstet. 59. 569

Curtillet, E., and Curtillet, A. (1939a). C.R. Soc. Biol., Paris, 130. 645 C (1939b). Ibid., 130. 647.

Durant, T. M., et al. (1949). Amer. Heart J., 38, 481.

Forbes. G. (1944). British Medical Journal, 2, 529

Gordon. 1. (1945). Clin. Proc., 4, 135.

Moore, R. M.. and Braselton, C. W. (1940). Ann. Surg., 112, 212.

Shennan, T. (1935). Post-mortems and Morbid Anatomy, p. 153. Arnold. London.

Simpson, K. (1942). Lancet, 1. 697.

Application has been made by the French Government on behalf of Morocco for admission as an Associate Member of the World Health Organization, and will be submitted to the Fifth World Health Assembly which opens in Geneva on May 5. Of the 79 countries which have joined W.H.O.. Southern Rhodesia is so far the only Associate Member.

\section{PROLONGED ANTICOAGULANT THERAPY WITH HEPARIN}

\author{
BY
}

ALLAN WYNN, M.D., M.R.C.P. Registrar, Cardiac Department, St. Thomas's Hospital formerly Registrar, Postgraduate Medical Schoal of London, $W .12$

JOHN F. GOODWIN, M.D., M.R.C.P.

Physician and Lecturer, Department of Medicine. Postgraduate Medical School of London, W.12

AND

\section{ANGELA BIRBECK}

The use of the anticoagulant drugs dicoumarol and "tromexan" in the treatment of thrombo-embolic disease is restricted to institutions equipped for performing daily prothrombin estimations. There is, therefore, a need for a safe anticoagulant which can be used where facilities for this test are not available. Heparin would be suitable if the practical difficulties associated with its prolonged intravenous administration could be overcome. The use of an indwelling needle has been recommended by Jorpes (1946) and Forrester (1949), and finebore polythene tubing by MacFadyen (1949) to avoid frequent venepuncture. When more than ten days' treatment is required it is usually necessary to resort to intramuscular administration.

In order to determine whether heparin could be satisfactorily administered for long periods, 37 patients with thrombo-embolic diseases were treated for periods of up to five weeks: 20 were suffering from acute myocardial infarction, 2 from acute coronary insufficiency, 7 from acute venous thrombosis, 4 from acute pulmonary embolism, and 4 from embolism of peripheral arteries.

\section{Techniques}

Intravenous Administration. - A needle or cannula with an attached Gordh adapter (Forrester, 1949) was inserted into a forearm vein at wrist level and strapped down. Heparin was given four-hourly in doses of $50-75 \mathrm{mg}$. through the diaphragm of the adapter. A fine-bore polythene tubing was also used, but it was found to be less satisfactory than a needle, except when the only suitable vein was in the antecubital fossa. The flexible tubing then permitted free movement at the elbow.

Intramuscular Administration.-A concentrated aqueous solution containing $250 \mathrm{mg}$. of heparin per ml. (approximately equal to 25,000 Toronto units*) was used. Two ml. of $1 \%$ procaine was mixed with each dose of heparin, which was given through fine short needles (s.w.G. 23, 24, serum gauge VI). The heparin solution used initially was hypertonic, but later an isotonic solution of the same strength $\dagger$ was employed.

Estimation of Coagulation Times.-A modified Lee-White method was used (Quick et al., 1948). The average time taken for blood to clot in three dry tubes at $37^{\circ} \mathrm{C}$. in the patients undergoing anticoagulant therapy and in 50 normal controls was six minutes, the range being five to eight minutes. Coagulation times were estimated twice daily: one hour after intravenous, four hours after intramuscular injections, and again just before the next dose with both routes. These represent approximately the maximum and

*The preparation was standardized in units, and the number of units per mg. varied slightly from batch to batch.

+Pularin, supplied by Evans Medical Supplies Ltd., Liverpool. 
minimum prolongation of the coagulation time. Nine patients received intravenous heparin alone, 23 had intramuscular heparin alone, and five had intravenous followed by intramuscular heparin. Intravenous dosage was given for 3 to 14 days (average duration six days), intramuscular dosage lasted for 4 to 42 days (average duration 19 days). Alternative time/dosage schedules were often employed in the same subjects at different periods (see Table II).

\section{Results of Intravenous Administration}

Effect on Coagulation Times.-In most cases $50-75 \mathrm{mg}$. every four hours resulted in prolongation of the maximum clotting-time to levels of from 16 to 60 minutes. This prolongation was transient, and the minimum clotting-time was found to be almost normal at the end of four hours (Table I). When $75 \mathrm{mg}$. was given four-hourly there was

TABLE I.-Coagulation Times Produced with Intravenous Heparin

\begin{tabular}{|c|c|c|c|}
\hline \multirow[b]{2}{*}{ Dosage } & \multirow{2}{*}{$\begin{array}{l}\text { No. of } \\
\text { Cases }\end{array}$} & \multicolumn{2}{|c|}{ Coagulation Time (Lee-White) in Minutes } \\
\hline & & $\underset{\text { Range }}{\text { Maximum }} *$ & $\underset{\text { Range }}{\text { Minimum }}$ \\
\hline $\begin{array}{l}50 \mathrm{mg} \text { 4-hourly } \\
75, ",\end{array}$ & $\begin{array}{r}12 \\
2\end{array}$ & $\begin{array}{l}41-16 \\
60-24\end{array}$ & $\begin{array}{l}14-6 \\
15-8\end{array}$ \\
\hline
\end{tabular}

* The maximum and minimum readings are those one hour after an injection and just before the next injection respectively.

no significant summation of effect over a period of five days. Cumulative action resulted when larger doses were used, as in one patient who was given $125 \mathrm{mg}$. four-hourly in error. By the third day the minimum coagulation time was over 60 minutes, although the patient suffered no untoward effects other than a brief rigor, and no haemorrhage other than slight oozing of blood round the needle.

Local Reactions.-The duration of intravenous heparin therapy was restricted by the development of local infection round the indwelling needle. However, it was usually found unnecessary to change the site of the needle before the fifth or sixth day; in two cases the needle was retained for eight and ten days respectively before treatment was discontinued. By changing the site of the needle periods of 10 to 14 days' continuous therapy were achieved. Thrombophlebitis occurred in four cases, in three of which polythene tubing had been used.

\section{Results of Intramuscular Administration}

Effect on Coagulation Times (Table II).-The maximum effect of a single injection of $150 \mathrm{mg}$. of heparin was reached in three to four hours and was maintained above twice the normal clotting-time for 9 to 10 hours. There was no significant effect after about 12 hours, except in one case. Individual variation in heparin sensitivity, as has been reported for intravenous heparin (de Takats, 1943, 1950), was found to occur. In two cases which were more sensitive, a single dose of $150 \mathrm{mg}$. of heparin produced coagulation times of 30 and 20 minutes respectively at the end of 12 hours. Heparin resistance was demonstrated in another case in which $150 \mathrm{mg}$. prolonged the clotting-time for only six hours. An isolated injection of $250 \mathrm{mg}$. of heparin pro-

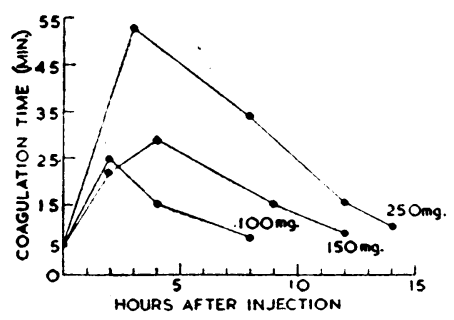

Fig. 1.-The effect of isolated doses of $100 \mathrm{mg}$., $150 \mathrm{mg}$., and $250 \mathrm{mg}$. of heparin respectively, given intramuscularly in the same patient.
of longed the coagulation time to at least twice the pre-heparin level for 12 hours. Fig. 1 shows the response to isolated intramuscular doses of 250,150 , and $100 \mathrm{mg}$. Although the response to single doses on different occasions was somewhat variable, the curves are representative of the' average effect of these doses.
TABle II.-Coagulation Times Produced by Prolonged Intramuscular Administration of Heparin

\begin{tabular}{|c|c|c|c|c|c|}
\hline \multirow{2}{*}{$\begin{array}{l}\text { Heparin } \\
\text { Dose }\end{array}$} & \multirow{2}{*}{$\begin{array}{l}\text { Case } \\
\text { No. }\end{array}$} & \multirow{2}{*}{$\begin{array}{c}\text { Duration } \\
\text { of } \\
\text { Treatment } \\
\text { in } \\
\text { Days } \\
\end{array}$} & \multirow{2}{*}{$\begin{array}{c}\text { Normal } \\
\text { Coagula- } \\
\text { tion } \\
\text { Time }\end{array}$} & \multicolumn{2}{|c|}{$\begin{array}{c}\text { Coagulation Times } \\
\text { (Lee-White) (Minutes) }\end{array}$} \\
\hline & & & & $\underset{\text { Range }}{\text { Maximum* }}$ & $\underset{\text { Range }}{\text { Minimum* }}$ \\
\hline $\begin{array}{l}100 \mathrm{mg} \text {. } \\
\text { 8-hourly }\end{array}$ & $\begin{array}{r}2 \\
7 \\
10 \\
11 \\
13 \\
99 \\
26 \\
30 \\
34\end{array}$ & $\begin{array}{r}21 \\
8 \\
3 \\
0 \\
7 \\
2 \\
7 \\
76 \\
16 \\
4\end{array}$ & $\begin{array}{l}5 \\
7 \\
5 \\
6 \\
6 \\
8 \\
6 \\
5 \\
7\end{array}$ & $\begin{array}{l}28-20 \\
19-12 \\
30-21 \\
27-20 \\
32-24 \\
46-38 \\
33-26 \\
31-25 \\
38-30\end{array}$ & $\begin{array}{l}21-16 \\
11-9 \\
18-14 \\
16-12 \\
15-10 \\
36-28 \\
19-14 \\
17-13 \\
27-23\end{array}$ \\
\hline $\begin{array}{l}125 \mathrm{mg} . \\
\text { 8-hourly }\end{array}$ & $\begin{array}{r}1 \\
3 \\
4 \\
5 \\
17 \\
24 \\
26 \\
30 \\
33\end{array}$ & $\begin{array}{r}10 \\
13 \\
4 \\
4 \\
11 \\
5 \\
7 \\
4 \\
7\end{array}$ & $\begin{array}{l}5 \\
7 \\
5 \\
5 \\
5 \\
5 \\
6 \\
5 \\
5\end{array}$ & $\begin{array}{l}50-25 \\
32-26 \\
40-27 \\
24-16 \\
26-15 \\
30-18 \\
44-30 \\
39-26 \\
34-29\end{array}$ & $\begin{array}{l}22-14 \\
19-13 \\
28-15 \\
16-10 \\
15-10 \\
23-12 \\
24-17 \\
23-15 \\
26-13\end{array}$ \\
\hline $\begin{array}{l}\text { 150 mg. } \\
\text { 8-hourly }\end{array}$ & $\begin{array}{r}5 \\
8 \\
25 \\
30\end{array}$ & $\begin{array}{r}8 \\
23 \\
2 \\
5\end{array}$ & $\begin{array}{l}5 \\
5 \\
5 \\
5\end{array}$ & $\begin{array}{l}34-24 \\
23-14 \\
35-25 \\
42-30\end{array}$ & $\begin{array}{l}27-17 \\
15-8 \\
26-18 \\
28-18\end{array}$ \\
\hline $\begin{array}{l}150 \mathrm{mg} . \\
12 \text {-hourly }\end{array}$ & $\begin{array}{r}1 \\
2 \\
3 \\
4 \\
6 \\
7 \\
10 \\
13 \\
14 \\
15 \\
19 \\
20 \\
21 \\
22 \\
99 \\
12 \\
23 \\
25 \\
\end{array}$ & $\begin{array}{r}16 \\
2 \\
4 \\
13 \\
25 \\
20 \\
13 \\
24 \\
37 \\
6 \\
7 \\
20 \\
10 \\
1 \\
23 \\
19 \\
18 \\
8\end{array}$ & $\begin{array}{l}5 \\
5 \\
7 \\
5 \\
6 \\
7 \\
5 \\
7 \\
6 \\
5 \\
5 \\
8 \\
7 \\
7 \\
8 \\
7 \\
8 \\
5\end{array}$ & $\begin{array}{r}48-28 \\
30-26 \\
26-20 \\
30-20 \\
27-16 \\
22-15 \\
24-21 \\
53-28 \\
32-20 \\
50-38 \\
57-35 \\
49-32 \\
48-29 \\
120 \\
34-26 \\
30-24 \\
35-27 \\
28-20 \\
\end{array}$ & $\begin{array}{l}17-12 \\
16-13 \\
13-9 \\
16-11 \\
18-12 \\
17-10 \\
15-13 \\
22-16 \\
16-12 \\
22-16 \\
24-15 \\
21-12 \\
24-14 \\
30 \\
22-14 \\
15-12 \\
20-12 \\
15-10 \\
\end{array}$ \\
\hline $\begin{array}{l}250 \mathrm{mg} \\
\text { daily }\end{array}$ & $\begin{array}{r}30 \\
14 \\
1 \\
3\end{array}$ & $\begin{array}{l}2 \\
5 \\
4 \\
2\end{array}$ & $\begin{array}{l}5 \\
6 \\
5 \\
7\end{array}$ & $\begin{array}{l}54-46 \\
58-48 \\
35-28 \\
26-22\end{array}$ & $\begin{array}{l}7-6 \\
9-7 \\
8-4 \\
7-5\end{array}$ \\
\hline $\begin{array}{l}250 \mathrm{mg} \text {. } \\
12 \text {-hourly }\end{array}$ & $\begin{array}{r}30 \\
1 \\
3\end{array}$ & $\begin{array}{l}2 \\
2 \\
3\end{array}$ & $\begin{array}{l}5 \\
5 \\
7\end{array}$ & $\begin{array}{l}60-50 \\
48-32 \\
40-32\end{array}$ & $\begin{array}{l}26-18 \\
24-20 \\
24-16\end{array}$ \\
\hline
\end{tabular}

* The maximum and minimum readings are those four hours after an injection and just before the next injection respectively.

It will be seen that increasing the dose increases both the degree of prolongation of clotting-time and the duration of effect, the former being slightly more pronounced than the latter.

Local Reactions.-The isotonic solution was found to be less locally irritant than the hypertonic, and when the former was given with $1-2 \mathrm{ml}$. of $1 \%$ procaine the injections were well tolerated until the dose exceeded $150 \mathrm{mg}$. With larger doses local aching pain and stiffness frequently resulted within two to three hours. Painful nodules and haematomata occurred in half the patients, and in seven the injections had to be stopped. Three of these patients were elderly and were noted to have developed small bruises after injections of other drugs. All the haematomata resolved without complications, although one required aspiration. When the injections were given in the arms firm local pressure, applied after the injection for 15 to 20 minutes by means of a sphygmomanometer cuff inflated to $50-60$ $\mathrm{mm}$. $\mathrm{Hg}$, reduced the tendency to bruising. When the minimum coagulation time was maintained at more than twice normal, local bleeding increased.

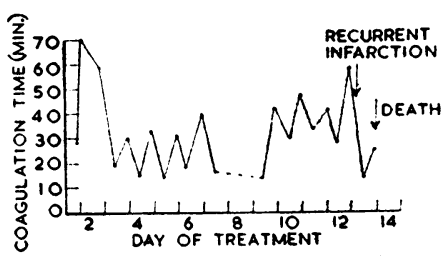

Fig. 2.-Fatal recurrent myocardial infarction occurring on the thirteenth day of treatment, despite adequate lengthening of coagulation time, in a patient hypersensitive to heparin. Dose of heparin: $150 \mathrm{mg}$. 12-hourly for two days and then $100 \mathrm{mg}$. 12-hourly. 
Therapeutic Results.-The effectiveness of anticoagulant therapy in thrombo-embolic disease clearly cannot be assessed from this small series, but the results are of interest. Twenty-six patients who received intramuscular heparin had no further thrombosis, but two patients suffering from myocardial infarction had further attacks which may have been thrombotic. The first had a clinically mild recurrence of infarction on the 25th day of treatment, despite the fact that $150 \mathrm{mg}$. of heparin 12-hourly had maintained the minimum coagulation time above 15 minutes throughout. The second patient had an acute episode suggesting a recurrent infarction on the 13th day of treatment and died the next day despite the high levels at which the clotting-times had been maintained (Fig. 2). Permission for necropsy was refused. This must be regarded as failure of heparin therapy rather than of the intramuscular route of administration.

\section{Comment on the Two Methods}

The intravenous route of heparin administration, using an indwelling needle with a Gordh adapter, is the method of choice when only 10 to 14 days' treatment is required. Intramuscular injections of heparin should be as small and as infrequent as is consistent with adequate anticoagulant effect, in order to reduce the severity of local reactions.

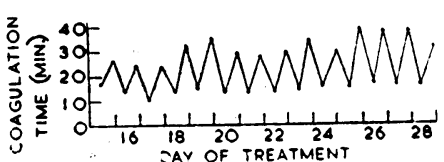

FIG. 3.-Daily coagulation times four and 12 hours after an injection in a case receiving $150 \mathrm{mg}$. of 'heparin intramuscularly 12-hourly. A stable prolongation at an adequate level was achieved.

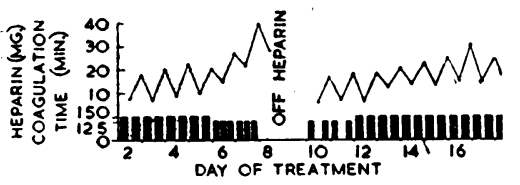

Fig. 4.-Coagulation times in a patient with myocardial infarction treated with intramuscular heparin, showing summation effect with a dose of $125 \mathrm{mg}$. eighthourly.

These can also be reduced by the use of a concentrated isotonic solution mixed with procaine, and firm pressure applied over the injection site after the injection.

We accepted the view of Allen et al. (1947) and Wood (1950) that the coagulation time should be prolonged to between two to three times the normal. $\mathrm{Th}$ is can be achieved by keeping the level before each dose at about twice the patient's normal (Fig. 3). Because of the longer action of intramuscular heparin, successive injections may summate if given too often, so that local reactions are increased.

A step-like progressive increase in levels was seen several times when the minimum coagulation times exceeded about 20 minutes (Fig. 4), and bleeding into the injection sites occurred. The results achieved with different dosage schedules (Tables II and III) show that, to maintain the minimum coagulation time at approximately twice the patient's normal, $150 \mathrm{mg}$. 12-hourly or $100 \mathrm{mg}$. 8-hourly was generally enough.

The greater effect of repeated injections of these doses compared with the isolated doses is due partly to the increase

TABLE III.-Results of Various Intramuscular Heparin Dosage Schedules

\begin{tabular}{|c|c|c|c|c|c|}
\hline \multirow{2}{*}{$\begin{array}{l}\text { Dose } \\
\text { in } \\
\mathrm{mg} .\end{array}$} & \multirow{2}{*}{$\begin{array}{c}\text { Time } \\
\text { Interval } \\
\text { Between } \\
\text { Doses }\end{array}$} & \multicolumn{3}{|c|}{ Effect on Coagulation Time* } & \multirow[b]{2}{*}{ Total } \\
\hline & & $\begin{array}{c}\text { No. of } \\
\text { Cases } \\
\text { Adequate }\end{array}$ & $\begin{array}{c}\text { No. of } \\
\text { Cases } \\
\text { Inadequate }\end{array}$ & $\begin{array}{c}\text { No. of } \\
\text { Cases } \\
\text { Excessive }\end{array}$ & \\
\hline $\begin{array}{l}100 \\
100 \\
125 \\
150 \\
150 \\
250 \\
250\end{array}$ & $\begin{array}{c}8 \text { hours } \\
12 \\
8 \\
12 \\
8 \\
12 \\
24\end{array}$ & $\begin{array}{r}6 \\
2 \\
7 \\
74 \\
0 \\
0 \\
0\end{array}$ & $\begin{array}{l}1 \\
0 \\
0 \\
2 \\
1 \\
0 \\
4\end{array}$ & $\begin{array}{l}2 \\
0 \\
2 \\
2 \\
3 \\
3 \\
0\end{array}$ & $\begin{array}{r}9 \\
2 \\
9 \\
18 \\
4 \\
3 \\
4\end{array}$ \\
\hline
\end{tabular}

- The criteria used for assessing the results on the coagulation times are explained in the text. in heparin sensitivity which occurs with treatment (de Takats, $1943,1950)$ and partly to the tendency to summation. Even with these doses, which are smaller than have been advocated by Abrahams (1950), excessive prolongation of the coagulation time was sometimes seen; the coagulation time should therefore be estimated every 24 hours, preferably just before an injection is due.

\section{Indications for Intramuscular Heparin}

There is evidence that intermittent intravenous injections of heparin are more effective than intramuscular heparin in the acute stages of a thrombotic process (Bauer et al., 1950). Jorpes (1950) ascribed this difference to the effect of the transient high peaks of action seen with intravenous (but not with intramuscular) injections upon the loose newly formed clots. The vasodilator action of heparin (Abrahams and Howarth, 1950) may also be less after intramuscular injection. For these reasons heparin should be given, if possible, intravenously in the acute stage of a thromboembolic illness and intramuscularly only in the later stages.

Intramuscular heparin may prove a useful form of domiciliary treatment for patients with myocardial infarction who present themselves a week or more after the onset of the illness, when it is often difficult to secure their admission to a hospital for treatment with coumarin drugs. Further study is needed to determine whether the dose of heparin which can safely be given in this way will significantly reduce the incidence of the thrombo-embolic complications of this disease.

De Takats (1950) has found intramuscular heparin in doses of 50-150 mg. 12-hourly to be useful as a prophylactic measure against post-operative venous thrombosis and pulmonary embolism. This dosage may be inadequate for treating established thrombotic conditions because of the decreased heparin sensitivity which is commonly seen after operation. This was illustrated by one of our patients who developed a myocardial infarction after a partial gastrectomy: $100 \mathrm{mg}$. of heparin intramuscularly eighthourly for eight, days failed to prolong the minimum coagulation time above 10 minutes.

Contraindications to Intramuscular Heparin.-Patients with a tendency to bruise easily from minor injuries, especially elderly persons with loose inelastic connective tissues, and those with considerably raised venous pressure, are unsuitable for intramuscular heparin administration because they are very liable to develop local haematomata.

\section{Summary}

Thirty-seven patients with thrombo-embolic diseases have been treated with heparin alone for periods up to five weeks in order to ascertain if this is an efficient and safe alternative to coumarin drugs for prolonged anticoagulant therapy, in circumstances which preclude the daily estimation of prothrombin times.

Heparin was administered intravenously in nine cases by means of an indwelling needle or polythene catheter with a Gordh adapter attached, intramuscularly in 23 cases, using a concentrated aqueous solution containing $250 \mathrm{mg}$. of heparin per $\mathrm{ml}$, and by both methods in five cases.

Estimations of the coagulation time were made by Quick's modification of the Lee-White method, and the dose of heparin was adjusted to maintain the minimum coagulation time at approximately twice the pre-heparin level. In most cases this could be achieved by $50-75 \mathrm{mg}$. four-hourly intravenously and $150 \mathrm{mg}$. 12-hourly intramuscularly.

Haematomata due to intramuscular administration occurred mainly when doses larger than $150 \mathrm{mg}$. were used ; when injections were given more often than 12hourly; if the minimum coagulation time was main- 
tained above 20 minutes; if the patient tended to bruise easily or had a considerably raised venous pressure ; and in elderly patients with lax inelastic subcutaneous tissues.

Local reactions were minimized by the use of an isotonic solution of heparin mixed with $1 \%$ procaine and by applying firm pressure over the injection site, but the development of haematomata prevented further administration of heparin in $25 \%$ of the cases.

Of the 37 cases 35 suffered no further thromboembolic incidents, one patient died after a clinically typical recurrent myocardial infarction, and another experienced a mild recurrent infarction despite adequate prolongation of the coagulation times.

We are grateful to Dr. R. Powell and to Evans Medical Supplies Ltd. for generous supplies of heparin (pularin) and for a grant to defray the expense of this work. We also wish to thank Professor J. McMichael and members of the staff of the Postgraduate Medical School for kindly referring some of the patients studied. Professor McMichael and Dr. C. L. Cope kindly gave advice on the preparation of the paper.

\section{REFERENCES}

Abrahams, D. G. (1950). Brltish Medical Journal, 2, 1418.

and Howarth, S. (1950). Brt. Heart J.. 12. 429.

Allen, E. V., Barker, N. W.. and Hines, E. A. (1947). Perlpheral Vascular Diseases, p. 725 . Saunders, Philadelphia

Bauer, G., Boström, H., Jorpes, E., and Kallner, S. (195n). Acta med. scand., 136, 188.

De Takats, G. (1943). Surg. Gynec. Obstet., 77, 39

Forrester). J. Amer. med. Ass., 142. 527.

Jorpes, J. E. (1946). Heparin in the Treatment of Thrombosis, 2nd ed Oxford Univ. Press, London.

Oxford Univ. Press, London.

(1950). Acta chir. scand., Suppl. 149.

MacFadyen, W. A. L. (1949). British Medical Journal, 2, 925.

Quick, A. J., Honorato, R., and Stefanini, M. (1948). Blood, 3, 1120 od, P. (1950). Diseases of the Heart and Circulation, p. 454 . Eyre \&
Spottiswoode, London.

\section{MITRAL VALVE DISEASE IN THE LIGHT OF SURGICAL TREATMENT}

\author{
BY
}

\author{
GEOFFREY BOURNE, M.D., F.R.C.P. \\ Physician in Charge of Cardiological Department,
} St. Bartholomew's Hospital

Successful valvulotomy for mitral stenosis has increased the necessity for careful clinical assessment. Three questions require an answer in every case: How much stenosis, how much regurgitation, and how much myocardial damage are present?

Disease of the mitral valve has long been classified under the two headings "mitral regurgitation" and " mitral stenosis." For some years I personally have preferred to think of this condition more generally as "mitral disease," since there are few cases of mitral stenosis in which some regurgitation does not occur, and there are many cases of mitral regurgitation in which there is probably also a sufficient degree of stenosis to influence the physical signs.

\section{Rheumatic Myocarditis}

The disease is always rheumatic in origin. The rheumatic inflammatory process attacks the muscle as well as the valve cusps. Assessment of the degree of rheumatic activity is important, for the state of the heart muscle in a case of mitral disease is good or bad in proportion to injury done to it by the rheumatic process. This process may be active or quiescent. The rheumatic inflammation varies enormously in acuteness or chronicity; the younger the case the more active is the infection. Furthermore, some cases have a pro- gressive course, while others become arrested at any stage of the disease. In a third group the process is at first slightly progressive, becoming arrested for a period of years, and then reverting to activity.

Subsidence of the activity of the disease at an early stage is responsible for those cases in which a valvular murmur is heard but in which the exercise tolerance is extremely good. I remember a miner who had come south during the war and who offered himself for military service. He had been active at the coal face until a few months previously, and on the day of the examination had no symptoms whatever. He had the typical physical signs of mitral stenosis - that is, a presystolic and diastolic murmur at the apex. A second case was that of a centre-forward of one of the best London amateur football clubs who had first-class exercise tolerance but physical signs similar to that of the other case. Here the process must have become arrested at a sufficiently early stage for the muscle to have escaped disease and for insufficient narrowing to have occurred to obstruct the normal blood flow. It is therefore important to try to estimate the extent of this inflammatory activity in each case. A history of recent sore throat or of joint pains, together with an increase in the sedimentation rate and white cell count, points to activity. Changes in the cardiogram may also be suggestive.

\section{Rheumatic Valvulitis}

Normally the mitral valve is closed efficiently by ventricular systole. In mitral stenosis the cusps themselves become thickened, shrunken, and adherent to one another down their free edges for a varying distance, and, furthermore, mural endocardial change may cause some shrinking of the valvular orifice itself. This process in the cusps is at first fibrotic, but in many cases calcification occurs in addition. The exact physical state is of importance to the surgeon, for the structure of the cusps will determine the ease or difficulty of separating them. The mitral cusps as viewed from above lie obliquely. If the mitral valve is regarded as a clock face, the two cusps are so placed that their edges when they meet would roughly take the line of 10 o'clock to 4 o'clock. The antero-medial cusp which covers the upper right face of the "clock" is of great importance, since as it projects down into the left ventricle it directs the blood flow from the ventricle towards the aorta. Should it become injured, not only will mitral regurgitation of a considerable extent occur but its influence on the proper direction of the blood as it leaves the ventricle will be correspondingly modified.

At first view one would think that the chief importance of valvulotomy for the treatment of mitral stenosis would be the enlargement of the mitral orifice. A second additional therapeutic consequence of a successful operation, however. is to free the cusps from one another. The resulting increased mobility may enable them to come together more perfectly with ventricular systole. The operation, therefore, not only alleviates the stenosis in such cases, but it may decrease the regurgitation which is so often present. Speaking still in terms of the mitral cusps, the performance of an operation by no means guarantees that the patient's heart will remain in good health, but it is probable that after the age of 30 recrudescence of an acute rheumatic valvulitis becomes less likely, and therefore perhaps that a second adhesion of the cusp edges, divided by operation, will be slower in developing.

\section{Mitral Regurgitation}

The two lesions-mitral regurgitation and mitral stenosis -should be considered separately, since the physical problems involved, as regards both the patient's cardiac efficiency and the possible help from surgery, are separate in the two conditions. In mitral regurgitation there is no narrowing of the mitral orifice, and the inflow of blood from the left auricle to the left ventricle is not lessened. The output to the systemic circulation is adequate for all purposes. The circulatory effect of mitral regurgitation is therefore almost negligible. The total output from the left ventricle, 